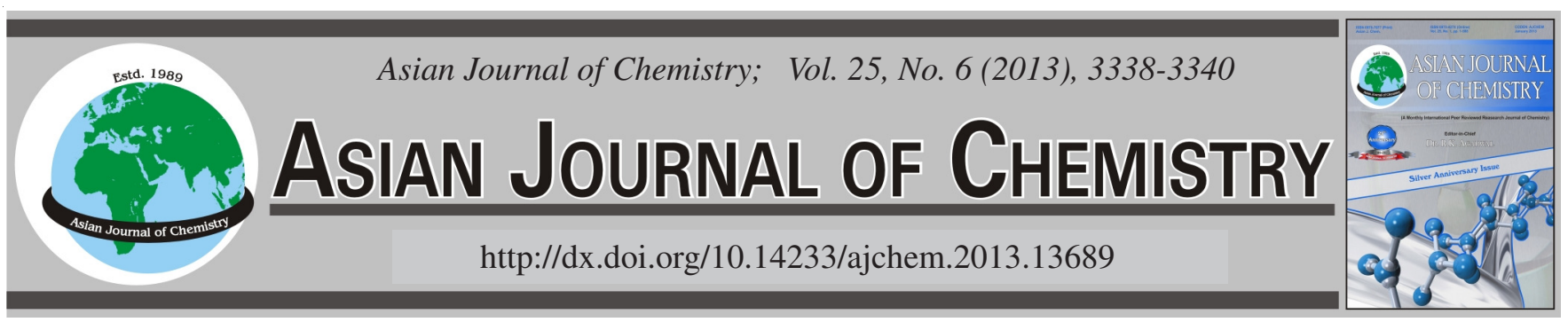

\title{
Effect of Different Cu Levels on Growth of Earthworm, Eisenia fetida in a Calcareous Soil
}

\author{
Raheleh Jenabi Haghparast ${ }^{1, *}$, Ahmad Golchin $^{2}$ and Ehsan KahneH ${ }^{3}$
}

${ }^{1}$ Jehade Agriculture Organization of Lahijan, Lahijan, Iran

${ }^{2}$ Department of Soil Science, Zanjan University, Zanjan, Iran

${ }^{3}$ Department of Soil Science, Ferdowsi University of Mashhad, Mashhad, Iran

*Corresponding author: Fax: +98 141 2223410; Tel: +98 141 2228101; E-mail: r.jenabi@yahoo.com

(Received: 7 March 2012;

Accepted: 19 December 2012)

AJC-12581

Destructive effects of heavy metals on the environment and the microorganisms have been reported. Heavy metals such as Cu break through different ways into agricultural land and the environment. In order to study effects of soil contamination concentrations, $0,10,20$, 40, 60, $80 \mathrm{mg} \mathrm{Cu}$ concentration per kg soil have been tested on the growth of earthworm species Eisenia fetida. The results showed that average concentrations of $\mathrm{Cu}$ up to $60 \mathrm{mg} / \mathrm{kg}$ soil increased and stimulated earthworm growth parameters. But higher concentrations 80 $\mathrm{mg} / \mathrm{kg}$ soil have significant negative effects on the mean weight, survivability and number of Cocoon produced. Amount of $\mathrm{Cu}$ in earthworm organs was a linear function of the $\mathrm{Cu}$ concentration in its living environment.

Key Words: Earthworm, Cu, Contamination, Survivability, Growth, Cocoon.

\section{INTRODUCTION}

Metal contaminants are causing destruction of soil ecosystems through affecting the structure of invertebrate earthborn creatures' populations ${ }^{1}$. Successful protection of these communities requires deep understanding of metal eco-physiology processes in invertebrates and their success in detoxification of metals ${ }^{2}$. Potential hazards of environmental contaminants to soil invertebrates during recent years have been analyzed using earthworms ${ }^{3}$, so that Eisenia fetida earthworm species has been selected for this purpose ${ }^{4}$. Toxicity of heavy metals on earthworms is different. In addition to the negative effects of heavy metals on the earthworms, subcutaneous heavy metal concentrations could reduce worms' growth and proliferation. Such metals can accumulate in earthworm tissues and regarding food pyramid cycle may be potentially harmful, because worms used by a wide range of terrestrial animals ${ }^{5}$. Copper is one of the metal contaminants in land ecosystems through different ways ${ }^{6-8}$. Some researchers have reported negative effects of high $\mathrm{Cu}$ concentrations on earthworms. Bindesboll et al. ${ }^{9}$, studies revealed that the $\mathrm{Cu}$ contaminations up to $200 \mathrm{mg}$ concentration in one $\mathrm{kg}$ soil has no effect on survivability of Dendrobaena octaedra earthworm. Their results also showed that over 10 weeks in the soil having $80 \mathrm{mg} \mathrm{Cu} / \mathrm{kg}$ soil, earthworms' weight were significantly higher than the weight of worms in the control treatment and other concentrations examined. Spurgeon et al. ${ }^{10}$, reported that in a clay loam soil contaminated with $\mathrm{Cu}$, low concentrations of $\mathrm{Cu}$ (10 and $40 \mathrm{mg} / \mathrm{kg}$ soil) stimulate the creatures growth, while concentrations of $160 \mathrm{mg} / \mathrm{kg}$ soil did not affect the growth procedure, however concentration of $640 \mathrm{mg} / \mathrm{kg}$ soil lead to decrease of growth rate and poisoning worms. Maboeta et al. ${ }^{11}$, analyzed fungicide oxy-chloride effect of $\mathrm{Cu}$ on Aporrectoda caliginosa earthworm species. Results showed that the mean weight of worms in the experimental control plots were 102 and $36 \mathrm{~g}$, respectively. Paoletti ${ }^{12}$ reported that particular types of fungicides that contain zinc and $\mathrm{Cu}$ are highly toxic for the earth worms. Spurgeon and Hopkin ${ }^{13}$ also reported significant reduction in Cocoon production in $\mathrm{Cu}$ contaminated soils by earthworms. According to studies conducted by Helling et al. ${ }^{7}$, critical limit of $\mathrm{Cu}$ oxy-chloride fungicide for growth and proliferation of Eisenia fetida earthworm species was $8.92 \mathrm{mg} / \mathrm{g}$ of environment context.

Recently, Gheisari et al. ${ }^{14}$ reported the growth and reproduction of Eisenia fetida in vermicomposting of organic fraction of municipal solid wastes. However, analysis of pollutants effects at the same time measuring their concentration in the environment could not represent the answer of living creatures to the contaminants, because of existing interactions and being time consuming. Due to quick responses of living organisms to changes in living locations, the present study is carried out to analyze the effects of different concentrations of copper on the growth of Eisenia fetida earthworm species. 


\section{EXPERIMENTAL}

Eisenia fetida earthworm species were prepared from Pars-Abad Moghan Industrial Cultivation Complexes. Worms were kept in $15 \pm 2{ }^{\circ} \mathrm{C}$ temperatures in moist soil using rotten cow manure (50\% soil and $50 \%$ manure). Soils were collected from the Poplar Research Station of Astaneh Ashrafieh. Some physicochemical properties of soil are presented in Table-1. Before using soils it was air-dried and were passed through a $2 \mathrm{~mm}$ sieve and stored at room temperature until its application. To create contaminant levels, Cu-chloride (Merck-Germany) was utilized in way that for the preparation of the various concentrations levels of $0,10,20,40,60$ and $80 \mathrm{mg} / \mathrm{kg}$ soil, the amount of needed salt after weighing was dissolved in distilled water and brought to the required size. After the splitting the soil to $3 \mathrm{~kg}$ box units, using the handy volume mist solution was added to the soil while stirring to be uniformly mixed with soil. The soil moisture was set $c a .50 \%$ water holding capacity. For balance purposes, the soils were incubated for a week. After this period, soils were again returned to the boxes. Each box was filled with 10 earthworms to analyze effects of $\mathrm{Cu}$ toxicity on the earthworm. Average weights of worms in the treatments were relatively equal. Boxes were kept in a greenhouse with a temperature range of $27-25^{\circ} \mathrm{C}$ during experiments. Weight losses of fresh earthworms were measured once every 15 -day period up to 75 days. To measure fresh worms' weight, they are completely immersed in water and weight of worms was determined after drying with paper filter. Then the worms were returned to boxes. Number of total Cocoon was also measured by the cultivation platform passed through $1 \mathrm{~mm}$ sieve. At the end of the experiments to determine the amount of $\mathrm{Cu}$ in the earthworm body, the worms were placed in Petri dishes for $48 \mathrm{~h}$ with wet filter paper so the contents of their intestines are unloaded. Then the worms were dried and digested using concentrated nitric acid and high temperature 9 . After that $\mathrm{Cu}$ concentration in the extracts were measured by atomic absorption device. Experimental design used in this study was repeated in three completely random procedures. Obtained data were analyzed using SAS software and ANOVA statistical analysis program. When a significant F statistics was obtained, comparisons with related average difference between treatments were calculated with LSD test.

\section{RESULTS AND DISCUSSION}

Survivability: Analysis of variance indicated that different concentrations of $\mathrm{Cu}$ had a significant effect on the survivability time of the worms. Copper concentration of 60 $\mathrm{mg} / \mathrm{kg}$ soil didn't show significant effects on the survivability however in concentrations of $80 \mathrm{mg} / \mathrm{kg}$ soil $4.5 \%$ casualties have been found in the worms (Fig. 1). Comparison of mortality during the time showed that the worms survivability have not a significant difference up to 45 days compared to the initial number, but after that more deaths and significant differences were revealed (Fig. 2).

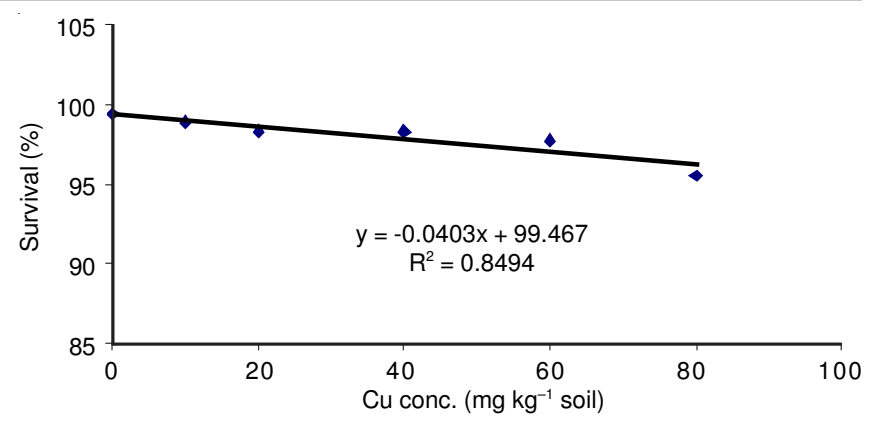

Fig. 1. Effect of Cu levels on survivability of E. fetida

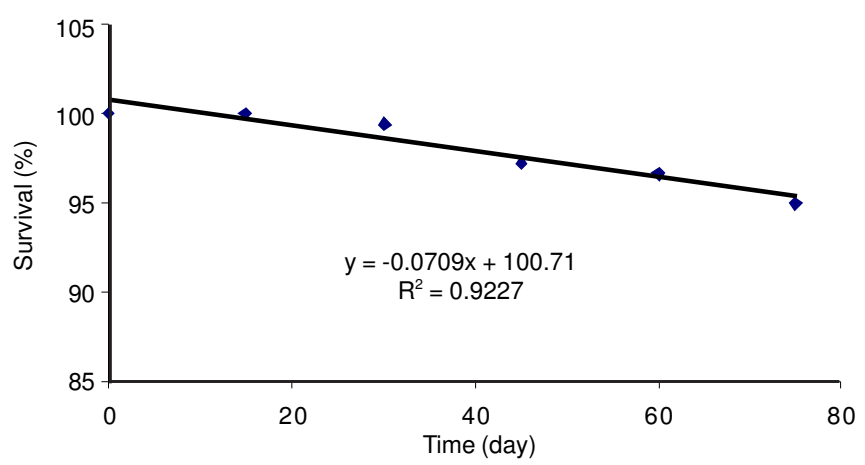

Fig. 2. Time duration effects on survivability of E. fetida

Growth: Worms' weight change chart within 75 days is presented in Fig. 3. Analysis of variance identified significant effect of $\mathrm{Cu}$ concentrations and time on the weight of the worms. With increasing $\mathrm{Cu}$ concentration up to $60 \mathrm{mg} / \mathrm{kg}$ soil, worms' weight increases however more increases in concentration drops the weight. Maximum average weight of worms was observed in the concentration of $60 \mathrm{mg} / \mathrm{kg}$ soil (Fig. 4). Worm weights increases over time and is a linear function of time (Fig. 5).

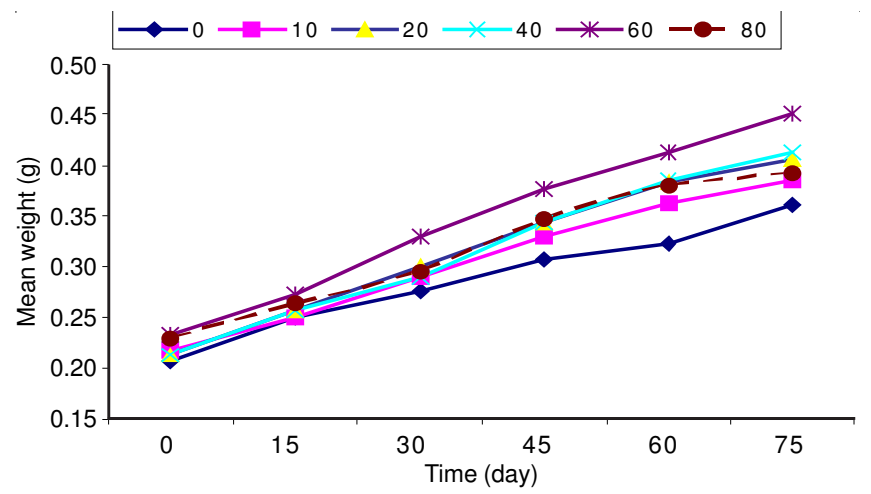

Fig. 3. Weight Change of E. fetida over time at different levels of $\mathrm{Cu}$ concentration

Copper concentration: Significant positive relationship was observed between $\mathrm{Cu}$ concentration in the body and the environment bed soil (Fig. 6). Earth worms showed zero to $37.17 \mathrm{mg} \mathrm{Cu} / \mathrm{kg}$ body weight in their limbs.

TABLE-1

SOME PHYSICOCHEMICAL PROPERTIES OF TESTED SOIL

\begin{tabular}{ccccccccc}
\hline $\mathrm{pH}(1: 2.5)$ & $\mathrm{EC} \times 10^{3}(1: 5)$ & $\mathrm{OC}(\%)$ & $\mathrm{N}(\%)$ & $\mathrm{P}\left(\mathrm{mg} \mathrm{kg}^{-1}\right)$ & $\mathrm{K}_{\left(\mathrm{mg} \mathrm{kg}^{-1}\right)}$ & $\mathrm{Cu}\left(\mathrm{mg} \mathrm{kg}^{-1}\right)$ & $\mathrm{CaCO}_{3}(\%)$ & Texture \\
\hline 7.6 & 1.2 & 1.34 & 0.06 & 13 & 194 & 7.8 & 9.3 & Clay loam \\
\hline
\end{tabular}




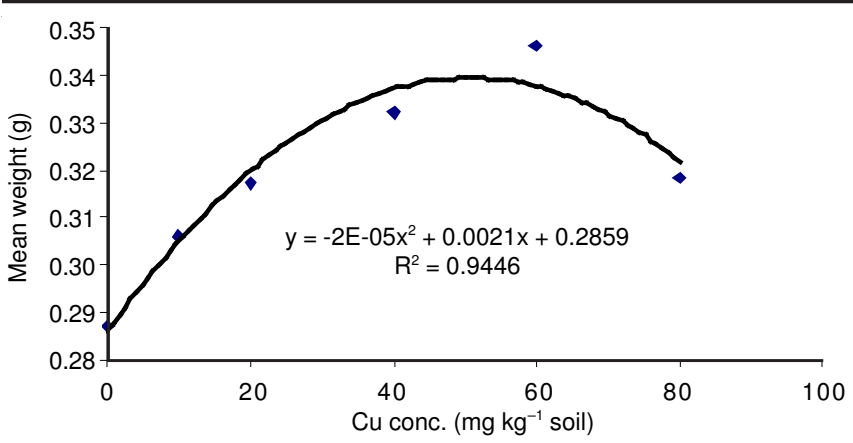

Fig. 4. Effect of different levels of $\mathrm{Cu}$ on the average weight of E. fetida

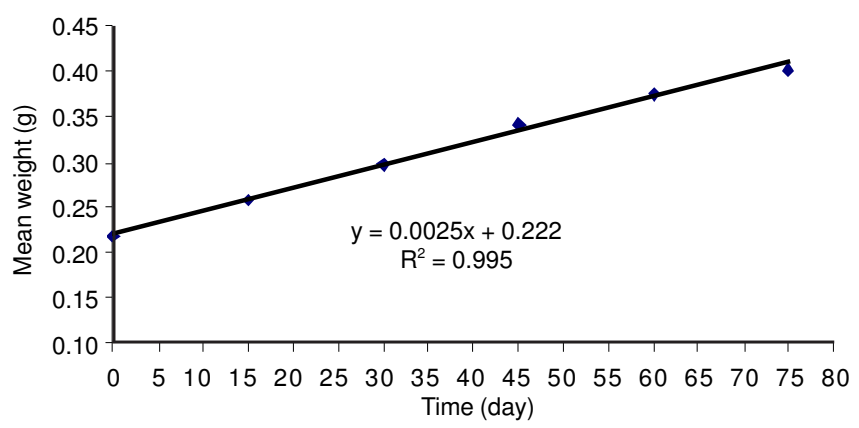

Fig. 5. Effect of time on average weight of E. fetida

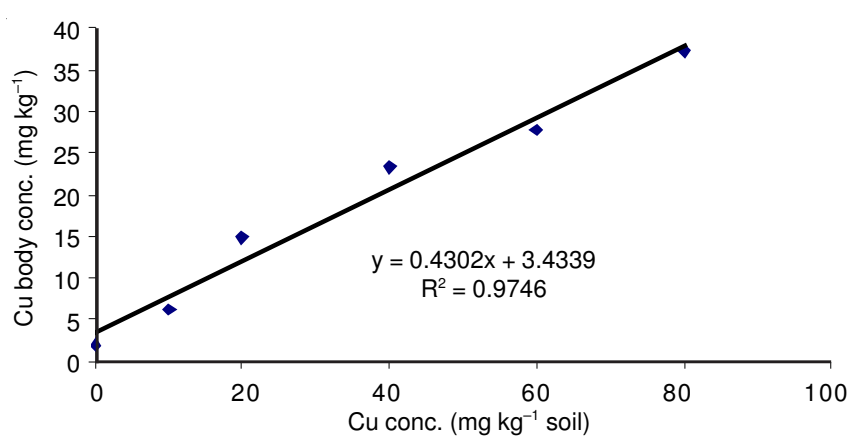

Fig. 6. Effect of different $\mathrm{Cu}$ levels on $\mathrm{Cu}$ accumulation in E. fetida organs

Cocoon production: Cocoon production began in the $9^{\text {th }}$ week. Worms tested under the $60 \mathrm{mg} \mathrm{Cu}$ concentration per one $\mathrm{kg}$ soil had been produced the maximum number of Cocoon (Fig. 7). At higher concentration levels the Cocoon numbers revealed to be declined and quadratic function of soil $\mathrm{Cu}$ concentration.

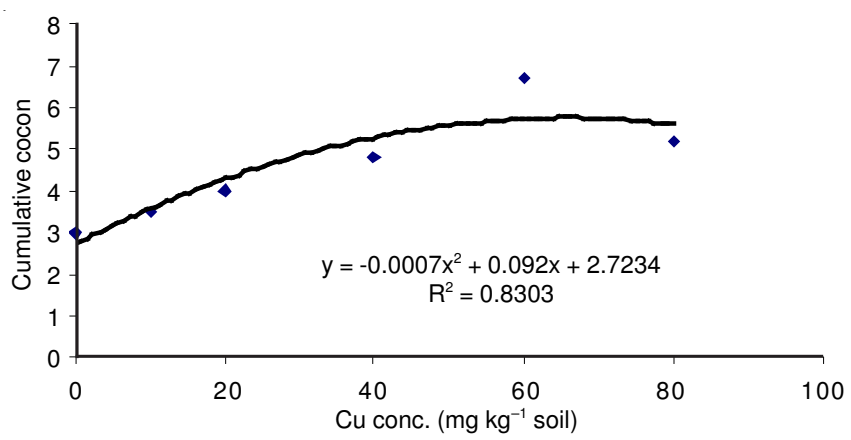

Fig. 7. Effect of different $\mathrm{Cu}$ levels on Cocoon production by E. fetida

\section{Conclusion}

The present study showed that average $\mathrm{Cu}$ concentrations encourage growth of E. fetida earthworm species. But the deterrent effect is likely in higher concentrations. Worm survivability in the $80 \mathrm{mg}$ concentration is affected and showed a significant decrease. Spurgeon et al. ${ }^{10}$, also reported that lower $\mathrm{Cu}$ concentrations $(40,10 \mathrm{mg} / \mathrm{kg})$ stimulate the growth of earthworm while higher concentrations of $640 \mathrm{mg}$ showed negative effects on worms' growth. Spurgeon et al. ${ }^{10}$, believe that growth stimulation in low $\mathrm{Cu}$ concentrations is due to Hormesis phenomenon. Stimulation effect occurs in low concentrations of a substance that is potentially toxic ${ }^{15}$, besides, such growth can be attributed to the effect of $\mathrm{Cu}$ antibiotics, leading to reduction of potential pathogens in earthworms. According to Gunnarsson and Rudgren ${ }^{16} \mathrm{Cu}$ significantly reduced the Cocoon contamination of Dendrodrilus rubidus earthworm species through nematodes effect.

Copper and zinc uptake by some of the earthworm are voided from the body by excretion mechanisms ${ }^{17}$. Mechanisms of metal link and remove, metabolic products consumed to improve survivability and recovery systems. This increased demand for more energy, certainly reduces available energy for growth and development ${ }^{18}$. Above mechanisms are effective in puberty and Cocoon production by the earthworm. Growth reduction of E. fetida earthworm species in concentration over $60 \mathrm{mg} / \mathrm{kg}$ of soil during the present experiment can be explained through spending more energy to dispose of much more than that of $\mathrm{Cu}$ absorption.

\section{REFERENCES}

1. D.J. Spurgeon, S.P. Hopkin and D.T. Jones, Environ. Pollut., 84, 123 (1994).

2. R. Dallinger and P.S. Rainbow, Ecotoxicology of Metals in Terrestrial Invertebrates, Lewis Publishers, Chelsea, USA (1993).

3. OECD, Guidelines for Testing of Chemical No. 207, Earthworm Actue Toxicity Tests, OECD, Adapted 4 April (1984).

4. H. Becker, P.J. Edwards, F. Heimbach and P.W. Greig-Smith, Ecotoxicology of Earthworms, Intercept Ltd., Hampshore, UK (1992).

5. P.J. Bohlen, Earthworms, Encyclopedia of Soil Science, Marcel Dekker, Inc., pp. 370-373 (2002).

6. A. Rozen, Eur. J. Soil Biol., 39, 73 (2003).

7. B. Helling, S.A. Reinecke and A.J. Reinecke, Ecotoxicol. Environ. Saf., 46, 108 (2000).

8. G. Bengtsson, H. Ek and S. Rundgren, Oikos, 63, 289 (1992).

9. A.M. BindesbØl, M. Bayley, C. Damgaard and M. Holmstrup, Appl. Soil Ecol., 35, 46 (2007).

10. D.J. Spurgeon, C. Svendsen, P. Kille, A.J. Morgan and J.M. Weeks, Ecotoxicol. Environ. Saf., 57, 54 (2004).

11. M.S. Maboeta, S.A. Reinecke and A.J. Reinecke, Ecotoxicol. Environ. Saf., 56, 411 (2003).

12. M.G. Paoletti, Agric. Ecosyst. Environ., 79, 137 (1999).

13. D.J. Spurgeon and S.P. Hopkin, Ecotoxicology, 4, 190 (1995).

14. S. Gheisari, S. Danesh and S.M. Mousavi, Asian J. Chem., 22, 1266 (2010).

15. A.R.D. Stebbing, Sci. Total Environ., 22, 213 (1982).

16. T. Gunnarsson and S. Rundgren, Pedobiologia, 29, 165 (1986).

17. J.E. Morgan and A.J. Morgan, Bull. Environ. Contamin. Toxicol., 47, 296 (1991).

18. M.H. Donker, C. Zonneveld and N.M. VanStraalen, Oecologia, 96, 316 (1993). 